\title{
Spatial distribution of solid waste dump site in Port Harcourt city, Rivers State, Nigeria
}

Richard J. U. ${ }^{1}$ and Ibochi Andrew Abah ${ }^{2}$

${ }^{1}$ Department of Special Survey, Office of the Surveyor General, Moscow Road, Port

Harcourt, Nigeria. jeremiah.uriah@yahoo.com

${ }^{2}$ Department of Surveying Bauchi State Polytechnic, Nigeria. andrewabah4real@gmail.com

The indiscriminate dumping of solid waste without proper regulatory frame work may caus surface and ground water contamination, and to a great extent affect the ecosystem. Solid waste also releases offensive odours into the environment. To minimize these challenges, the knowledge of the spatial distribution of solid wastes is essential in the management plan of waste collection and disposal. The spatial distribution of wastes location also assisted in determining it impact on land use/ land cover such as wetlands, water body, built-up, road network in the study area. The Port Harcourt city, Rivers State, Nigeria has been under intense pressure due to increase population from within and outside the state. The increase in population, industrial and economic activities in the area has contributed to the increase in the quantity of daily generated solid wastes in the city, which required prompt planning to regulate waste related diseases. This study utilized Landsat satellite image of year 2000, dump site location obtained with hand held GPS in UTM zone $32 \mathrm{~N}$ as input datasets, and ArcGIS 10.1 (vector software), and ENVI 5.0 (raster software) was used to performed the analysis. The Landsat image was classified into four (4) land use/ cover types; water body, wetlands, built-up, and vegetation. The image classification method adopted was maximum likelihood classification. The study applied buffer analysis $(150 \mathrm{~m}$ and $1000 \mathrm{~m}$ buffer zones) and spatial query from ArcGIS to determine the impact of dump site locations on land use/ land cover. The results of the buffer analysis perform on $150 \mathrm{~m}$ buffer zones of the three dump sites shows that six road layers were within this buffer zone. Similarly, 1000m buffer zone was query on wetlands, water body, built-up, and road layers, the results indicated that 174 wetlands polygons, 36 water body polygons, 42 built-up polygons, and 335 roads network were affected by the solid wastes dump sites location. The study discovered that the location of dump sites does not meet the required standard from road, built-up areas, water body, and wetlands and as such the inhabitants of the affected locations will be prone to solid wastes related diseases. It is therefore recommended that integrated approach on solid wastes management including collection, disposal, and processing should be adapted in the state, to minimized waste pollution.

Key Words: wetlands, solid waste, spatial query, land use/ land cover, Landsat image, buffer analysis

\section{Introduction}

Waste generally is defined as any material that is considered not useful and does not represent any economic value to the waste generator [1]. Solid Waste may be categorised according to its origin, contents, and hazardous potential. According to its origin it can be classified as household waste, institutional waste, and commercial waste [2]. Accordingly, [3] Categorize solid waste as general wastes (organics and recyclables), special wastes (household hazardous, medical, and industrial waste), and construction and demolition debris. 
In US, the Environmental Protection Agency (EPA) collects information on hazardous waste generation, management, and disposal [4]. Wastes generally constitute threat to the environment if not properly managed. Poorly manage or indiscriminate dumping of waste in an area will result to increase disease transmission rate, ground and surface water contamination, and discourage tourism [3]. Also, untreated waste has been identified as a major cause of pollution of Rivers, ill health and loss of crop productivity.

The primary assignment of Government at all level is to ensure adequate waste management policies driven by experts to achieved clean and healthy environment. Solid waste management is an integrated approach involving experts in the field of engineering, soil sciences, land use, hydrogeology, topography, sociology, and economics [5]. These professionals ensure that adequate management practice is put in place to management urban waste.

The quantity of solid waste generated in a city has been attributed by researchers to the urban population and the level of industrialization. In Port Harcourt city it is estimated that 117,825 tons/month solid wastes were generated [6]. The greater percentage of these wastes generated were dumped incessantly on the roads, drainages, unauthorized dump sites, and into water bodies [7]. In Rivers State, the Rivers State Environmental Sanitation Authority is the only agency established by law to regulate solid waste management including collection, transportation, and disposal in the state.

The spatial distribution of dumpsite location is an additional management procedure to wastes collection, transportation, disposal and processing. It is this spatial component that determined where a particular waste is located, which route to follow when collecting the waste and where it will be disposed [8]. Geographic information system (GIS) provides us with useful tools for the modelling the spatial distribution of solid waste in any geographic space. [9] Applied GIS to monitor spatial distribution of dump sites on critical infrastructure in Zaria, Kaduna State, Nigeria. GIS software also provides effective ways of managing landfills, vehicle routing, waste collection, recycling, hazardous materials, and site location [10]. GIS also provide support for making decision on selecting suitable location for sitting landfill $[11 ; 12 ; 13 ; 14 ; 15]$. As a very useful tool in decision making, GIS has been used in the investigation of potential of waste dump sites to contaminate ground and surface water using topographic data and other datasets $[16 ; 17 ; 18 ; 19]$. Besides solid waste, illegal oil activities and industrial pollution can as well pollute water bodies [20]. Application of GIS in waste management will prevent environmental degradation [21] and minimized disease outbreak, odour, economic loses, and atmospheric and water pollution [22].

[23] Used GIS software and GPS handheld receiver in Anand city of India to managed municipal solid waste collection, transportation, and disposal. This study is aimed at utilizing GIS as a tool for collection, storing, management, analysing, display, and modelling the spatial distribution of solid waste dump sites and to analysed its impact on land use/ land cover in the study area by integrating remote sensing data in the analysis.

\section{Study Area}

The study area has three dump sites namely, Igwuruta, Eliozu, and Rumuolumini dump sites distributed over the area. The Igwuruta dump site in Ikwerre Local Government Area is located in the northern part of the area with coordinate $281897 \mathrm{mE}, 545869 \mathrm{mN}$ and an area of $11.3 \mathrm{ha}$. The elevation of the dump ranges from $25 \mathrm{~m}$ to $30 \mathrm{~m}$ and the land use within the vicinity of the dump is built-up and farmland. The Eliozu dump site in Obio/Akpor Local Government Area is defined by coordinate $279768 \mathrm{mE}, 540409 \mathrm{mN}$ with an area of 6.1 ha, and the elevation ranges from $18 \mathrm{~m}$ to $22 \mathrm{~m}$ above mean sea level. The land use/ cover type surrounding the dump sites are built-up areas and wetlands. The Rumuolumini dump site in Obio/Akpor Local Government Area is located at the extreme south of the study area with 
spatial location $271695 \mathrm{mE}, 531558 \mathrm{mN}$ and the dump has a total area of 10.9 ha. The elevation of the dump site ranges from $7 \mathrm{~m}$ to $13 \mathrm{~m}$ above sea level and the land use pattern around the dump is built-up areas and water body (mainly salt water). The area is made-up of river network especially in the southern part and patches of wetlands around some of the dump sites location. It is densely populated with increase industrial and commercial activities capable of generating solid waste.

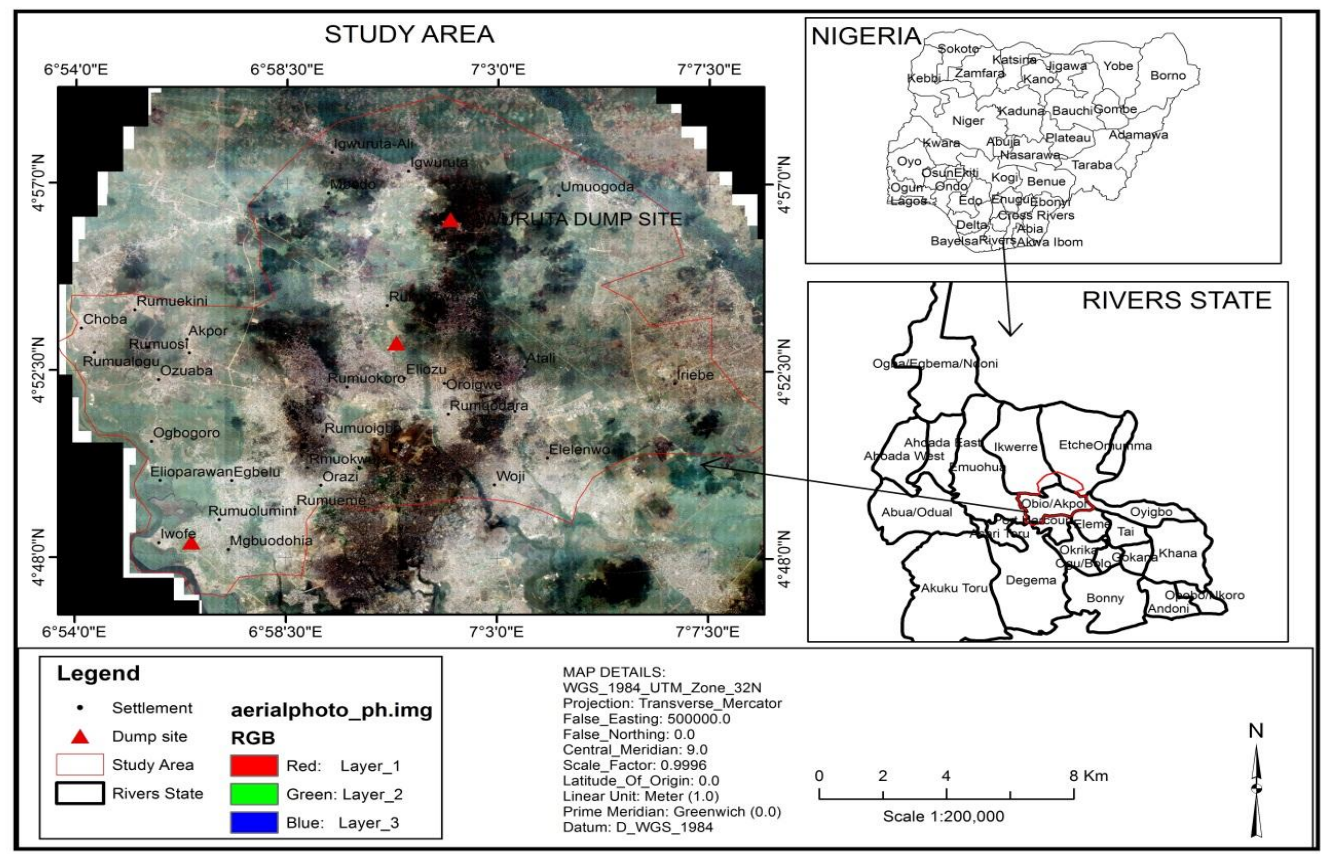

Figure 1. Study area location map showing spatial distribution of dumpsites marked red.

Table 1. Dump site location in the study area.

\begin{tabular}{|l|l|l|l|l|l|}
\hline DUMP SITE & TYPE & \multicolumn{2}{|c|}{ COORDINATE } & AREA (ha) & $\begin{array}{l}\text { LAND USE/ } \\
\text { COVER }\end{array}$ \\
\hline Eliozu & Open dump & $279768 \mathrm{mE}$ & $540409 \mathrm{mN}$ & 6.1 & $\begin{array}{l}\text { Built-up and } \\
\text { wetlands }\end{array}$ \\
\hline Igwuruta & Open dump & $281897 \mathrm{mE}$ & $545869 \mathrm{mN}$ & 11.3 & $\begin{array}{l}\text { Farmland and } \\
\text { Built-up }\end{array}$ \\
\hline Rumuolumini & Open dump & $271695 \mathrm{mE}$ & $531558 \mathrm{mN}$ & 10.9 & $\begin{array}{l}\text { Built-up and } \\
\text { water body }\end{array}$ \\
\hline
\end{tabular}

\section{Dataset and Software use}

In modelling the spatial distribution of dump site and the impact on natural and man-made feature both primary and secondary datasets were used in achieving the expected results. The study utilized dump site location defined by its coordinate obtained in UTM Zone 32N during site visit of the dump using Garmin 76CSx hand held Global Positioning System (GPS) receiver [24], 2008 aerial photograph of $0.2 \mathrm{~m} \times 0.2 \mathrm{~m}$ spatial resolution obtained from the office of the Surveyor General, Rivers State. This was used to extract road feature in the area and to show the spatial location of the three dump sites. The aerial photograph was chosen base on the high spatial resolution that enhances ground details and facilitate feature extractions. Also, band 432 of Landsat image of 2000 p188r57 with spatial resolution $28.5 \mathrm{~m}$ x $28.5 \mathrm{~m}$ downloaded from its website (http://glovis.usgs.gov/) was utilized for the purposed of extracting water body, built up, and wetlands areas that may be impacted by the dump site locations. Landsat 2000 was chosen because it is free from strip lines caused by failure of the 
Landsat Scan Line Collector in May 31, 2003 [25], [26], [27]. Although, using Landsat image of 2000 does not justify the current study as great change in the built-up around the dump site location may have taken place over these periods of sixteen years.

The software used for the study is ESRI ArcGIS 10.1 and ENVI 5.0. The choice of ArcGIS was based on its ability for vector operations. The ArcGIS 10.1 software was utilized to performed spatial analysis such as buffering and query, and for map compilations. While ENVI software was utilized for the classification and extraction of land use/ land cover types in the area.

\section{Methodology}

\section{Data Processing}

Data processing is an important stage in every GIS operation. It represents the stage where all data can be fully integrated into the GIS software for analysis. The dump site coordinates was typed in excel spread sheet in easting and northing column in UTM Zone $32 \mathrm{~N}$ coordinate system. The point data representing dump sites was plotting in ArcGIS 10.1, through the add data button. The points were overlaid on the auto photograph image used in the study, this is done to show distinctly the location, extent, and the relationship of the dump site with other surface features such as built-up, and water body. The 2000 Landsat image of the area was clipped in ArcGIS [28] using the shape file of the Local Government Area of Nigeria. Clipping the image reduced the image to the study area for direct application in the analysis. The clipped image extent was saved in tiff format and finally opened in ENVI for image classification. The classification method adopted was pixel based maximum likelihood supervised classification method [29]. The maximum classification method was selected for the study because of its higher classification accuracy as being reported by researchers. It is also the most common supervised classification method adopted in remote sensing image data processing [30]. The classification of image data was performed using Level 1 classification scheme as suggested by [31], [32]. During classification, the entire image data was grouped into four land use/ land cover types by selecting training areas for each land use/ cover category. These include; vegetation, water body, wetlands, and built-up area. After classification of the image in ENVI, each feature from the classification result was converted to shape file for further use in ArcGIS analysis. The classification accuracy assessment was also performed using the classification image and the reference image. The overall accuracy obtained in this classification was $99.73 \%$ and a kappa coefficient of 0.996 was also obtained, indicating high degree of accuracy of classification. The ultimate gaol in this classification was to have surface features that can be used to carry out analysis that support impact of dump sites spatial distribution on these land use.

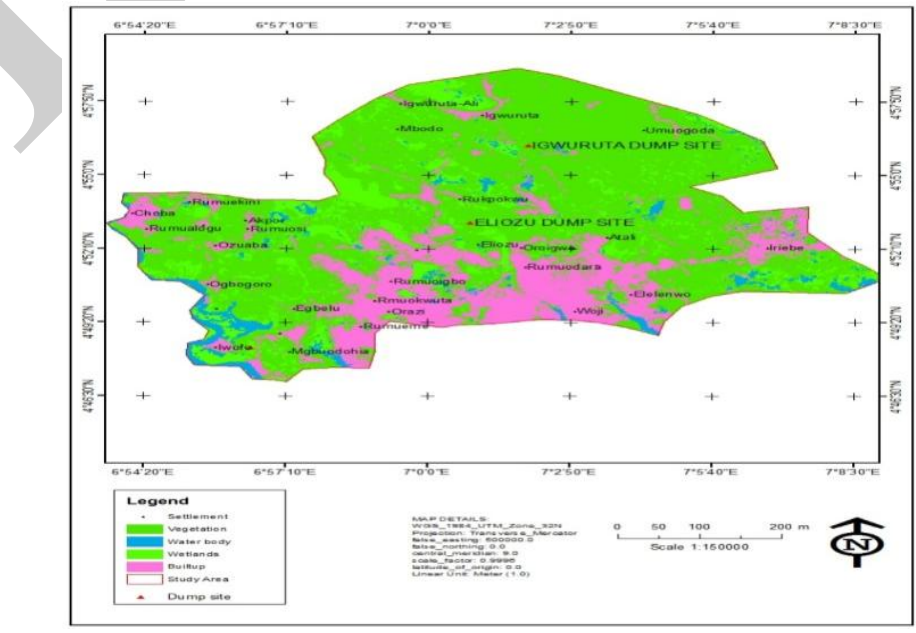

Figure 2. Classification map of the study area. 


\section{Buffer Analysis}

Buffering analysis is a spatial analysis operation found in ArcGIS. It is used to create specific distance around a feature, and this region is called buffer zone. Buffering operation has so many series of uses especially when combine with other spatial data layers [33]. Buffer analysis was used in locating slums from the city centre [34], and for determining impact of air pollution over a given distance [35]. In solid waste management, buffer operation may be useful in determining recommended distance of dump sites location from social and economic infrastructure. However, there are different specifications of distance of dump sites from infrastructure as cited by different researchers and this varies from country to country. [36] Quoted distance of not less than $152 \mathrm{~m}$ (500ft) as the recommended minimum distance of dump site to residential areas. Also, [37] quoted $150 \mathrm{~m}$ as the recommended distance of dump site to streams. While according to (Chang et al 2007) a distance of not less than $750 \mathrm{~m}$ away from road, not less than $1 \mathrm{~km}$ from well-water and rivers, and between $150 \mathrm{~m}$ to $5 \mathrm{~km}$ from urban areas was recommended as standard buffer zones for siting landfill (as cited in [38]). However, study had it that in Juba for example, the nearest dump site location was $300 \mathrm{~m}$ from structure and $1.5 \mathrm{~km}$ from the nearest community [39]. In this study, a buffer distance of $150 \mathrm{~m}$, and $1 \mathrm{~km}$ was carried out from the ArcGIS buffer wizard so as to determine the impact of solid waste on natural and man-made features. The point feature used for buffer analysis is the coordinate of the centre of each of the dump sites location distributed over the study area. The buffer zones was overlaid on the feature class (vegetation, water body, wetlands, and built-up) and spatial query [33] was initiated on the data. Query generally is a means of data retrieval from the database. The spatial query determines areas impacted by the dump site locations.

\section{Results and Discussion}

The query operation was performed using buffer zone of $150 \mathrm{~m}$ on the road network as shown in figure 3 below. On this buffer zone, a total of six roads were either within or intersecting the three dump site location as being displayed in the attribute table. Also, the highlighted roads on the map are the road features that are within this buffer zone of $150 \mathrm{~m}$ from dump sites. The study also observed that each dump site has at least a road that is within this buffer radius of $150 \mathrm{~m}$. The danger of this is that the dump site will constitute environmental hazard to the road users. The indiscriminate dumping of solid waste without proper planning relative to the road network as it is being observed posed serious air and land pollution [40]. The road users may be exposed to the effect of airborne disease such as cough, asthma, cancer, lung disease, etc. that are life threaten.

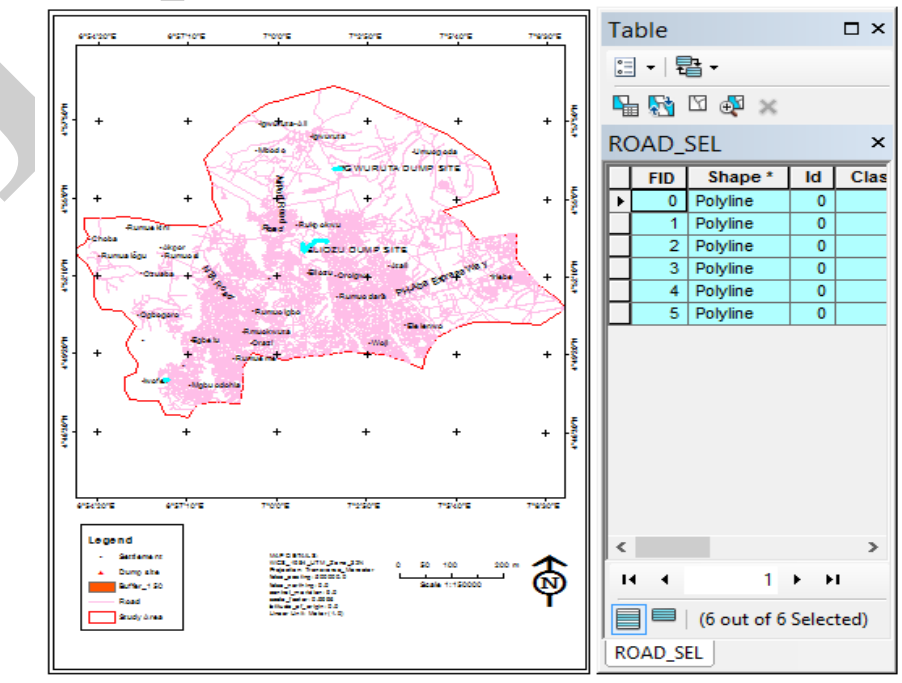

Figure 3. Query report on road network at $150 \mathrm{~m}$ buffer. 
Similarly, 1000m buffer zone was created using buffer wizard and overlaid on the digitized road network of the area as shown in figure 4. The query analysis was performed on the buffer zone, the result of the query was displayed in figure 5 below. The result of the spatial query analysis shows that 335 out of 11927 roads network where either directly within or intersecting the buffer zones. This implied that all the inhabitants of the area will be affected by the offensive odour, disease, and presence of reptiles associated with indiscriminate solid waste disposal. The buffer zone of the Eliozu dump site has the highest road network with some traversing in all direction of the $1000 \mathrm{~m}$ buffer zone. These roads network is as a result of development in built-up occasion by the centrality of the area to other part of the city.

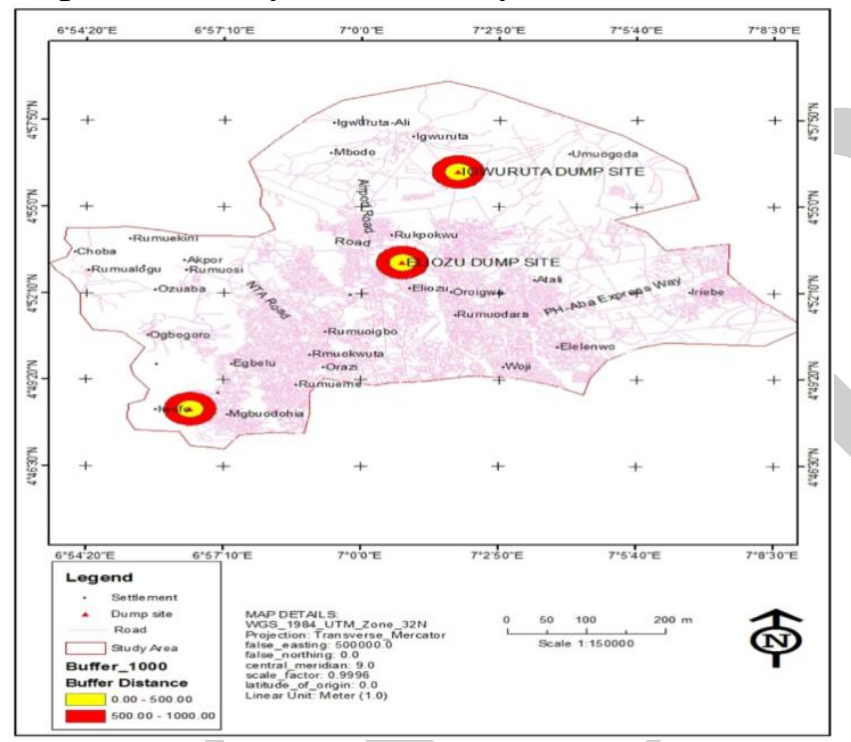

Figure 4. Overlay of $1000 \mathrm{~m}$ buffer on road network.

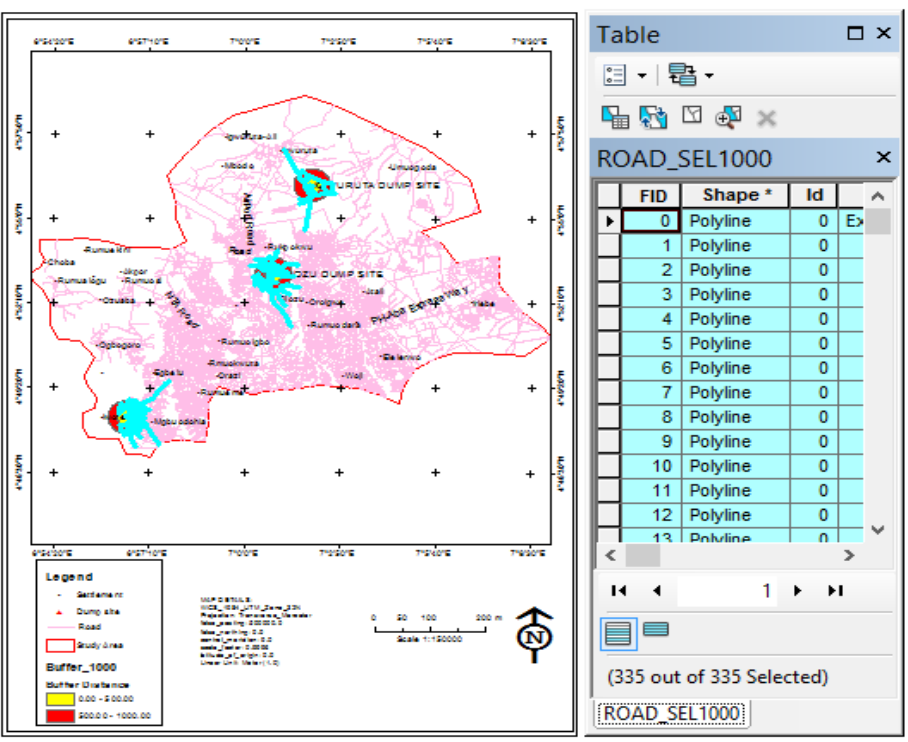

Figure 5. Query report on road network at 1000m buffer.

The dump site $1000 \mathrm{~m}$ buffer zone was overlaid on the classification map of the area as shown in figure 6 . The classification map represents the surface features that may be impacted by the indiscriminate dump site locations, and they include; vegetation, water body, wetlands, and built-up area. However, the concern is on the three land use/ cover (water body, wetlands, built-up area) with greatest impact, and from which this impact is propagated to human beings. This impact was investigated using a query operation on a $1000 \mathrm{~m}$ buffer zone on 
built-up areas as shown in figure 7. In this analysis, the study used cluster of building instead of individual buildings due to the large study area. The query report indicated that 42 out of 1425 polygons were selected for being within the buffer zones. The total building polygons affected has an area of 157.97 ha, with greater numbers of these buildings found around Rumuolumini dump site in the southern part of the map. The high concentration of buildings in this area may be due to the presence of college of education, now university of education in the area. The inhabitants of these areas will be exposed to flies, and rodents which are vectors of disease [41]. For instance, Rat from the recent study was the carrier of Lassa fever which are rampaging the whole world. Flies and rodents in a dump site multiply rapidly due to the presence of abundant waste foods and after which colonized the environment. Also, depending on the slope some inhabitant will be exposed to water borne diseases such as cholera, guinea worm, dysentery, and typhoid fever as a result of drinking, bathing, or cooking with contaminated water.

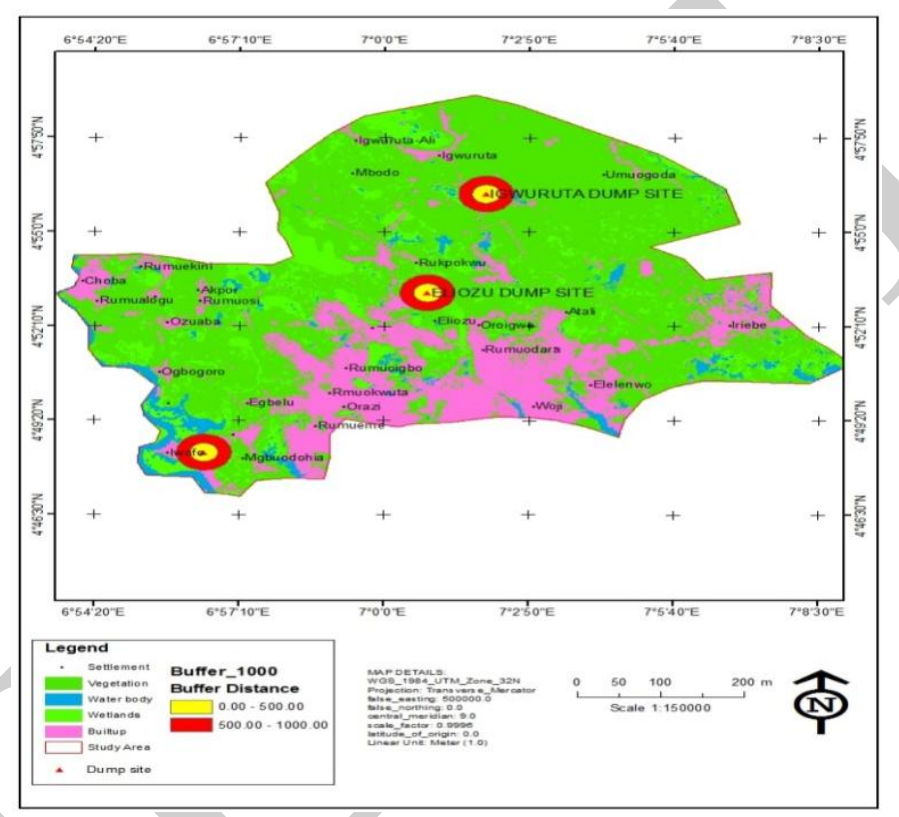

Figure 6. Overlay of $1000 \mathrm{~m}$ buffer on classification map.

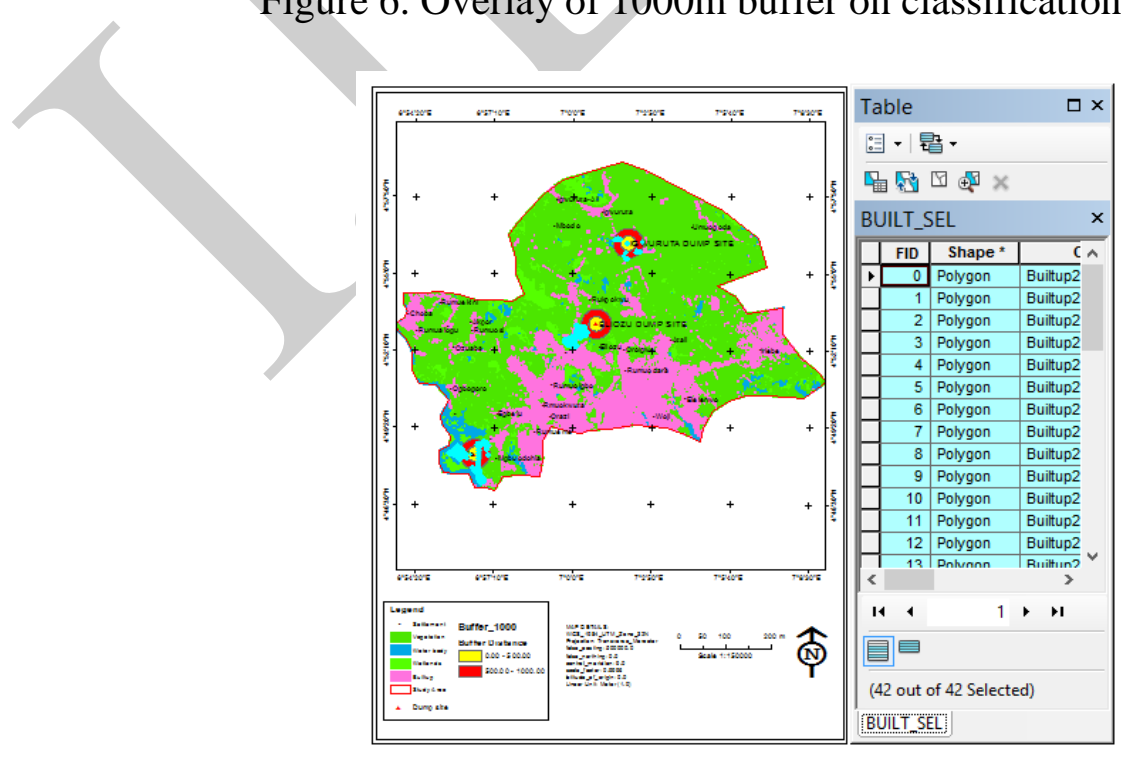

Figure 7. Query report on built-up at 1000m buffer zone. 
Similarly, for identifying impacted water body at each dump site location, a query operation on $1000 \mathrm{~m}$ buffer zone was initiated. It was discovered that a total of 36 water body's polygons were within the buffer zones. The majority of this water bodies were found around Rumuolumini dump site which is situated in the southern end of the area and bounded by the salt water of the Atlantic Ocean. The dump site at Eliozu has no water body within this buffer zone, while very little was seen around Igwuruta dump site. The water body serves as conduit for pollutants including solid wastes. As very important natural asset that is freely giving to human, water is needed for drinking, cooking, agricultural activities, washing, and for recreational purposes. Solid wastes affect water quality through physical, chemical, and biological means [41]. The location of the dump sites, especially, Rumuolumini dump was below the acceptable standard which portends great danger to neighbourhood and coastal communities [20].

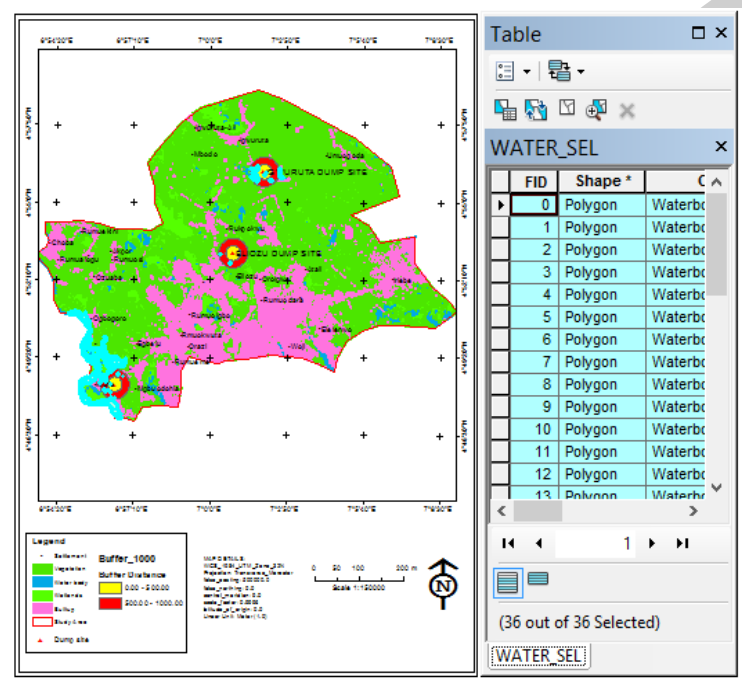

Figure 8. Query report on water body at $1000 \mathrm{~m}$ buffer zone.

The $1000 \mathrm{~m}$ buffer zones were queried using select by location from the ArcGIS main menu. The query results show that 174 wetlands out of 6308 polygons were within the buffer zones. There was high concentration of wetlands around Eliozu dump site, which was followed by the Rumuolumini dump site. The wetlands was few at the Igwuruta dump site, this is due to the upland nature of the area. The wetlands around Eliozu, and Rumuolumini dump site were interconnected and have its source from the Rumuolumini Rivers. The other wetlands in the eastern part of Eliozu dump have its source from the Abuloma River. The interconnectivity of these wetlands will enhance movement of contaminants from one location in higher slope to another location in lower slope. The contaminants from solid wastes will flow from Eliozu dump site at elevation of $22 \mathrm{~m}$ above mean sea level to Rumuolumini dump site at elevation of $7 \mathrm{~m}$ through the swampy wetlands, with severe consequence on the water quality [42], [43]. Solid waste contaminants can pervade the area following this movement through the wetlands and have adverse impact on the ecosystem. These will affect the ecological, economical, and aesthetic functions of wetlands [44]. Solid waste contamination of wetlands will equally contaminate ground and surface water because of the recharging ability of wetlands on water bodies, and this process has resulted in so many illness and death of people from water pollution, especially those who relied on streams and ponds as source of drinking water. 


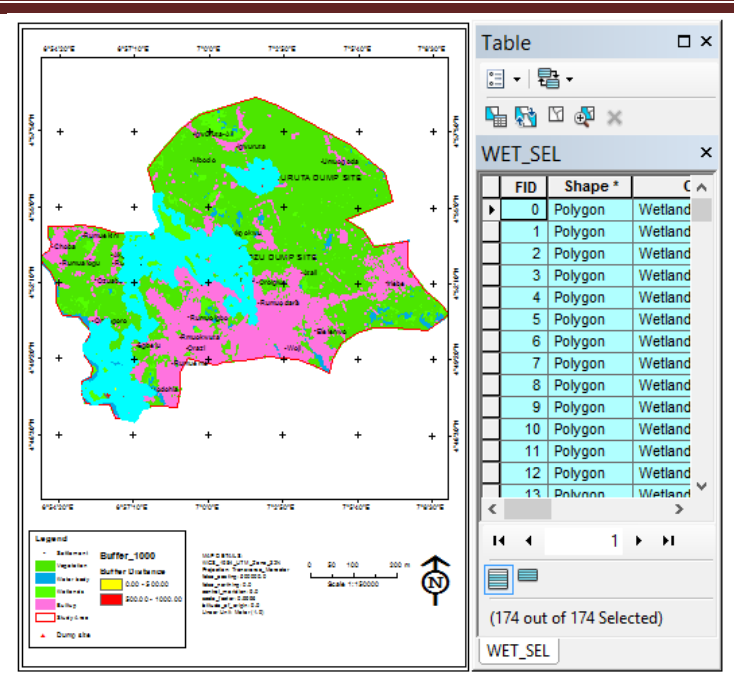

Figure 9. Query report on wetlands at 1000m buffer zone.

\section{Conclusion}

The indiscriminate dumping of solid wastes on roads, water bodies, farmlands, abandon properties, and built-up areas has been a serious concern to the government at all levels. Solid wastes are very harmful if not properly handle by the designated authority or agency of government. It also makes the physical environment untidy when they are disposed indiscriminately on the physical infrastructure such as roads, schools, churches and mosques, offices, and shops. Knowledge of the spatial distribution of solid wastes in an area is needed for effective management of waste collection and disposal. Geographic information system can be used to collect, store, analyse, manipulate, and present the map of the spatial distribution of solid waste dump site, which will aid policy makers on waste management authorities in the state. The study utilized the coordinate of dump site location in UTM coordinate system and satellite image as input data. Buffer analysis and spatial query was performed on the classification map at $150 \mathrm{~m}$ and $1000 \mathrm{~m}$ buffer zones respectively, to ascertain the impact of solid wastes dump sites on land use/ land cover in the study area. The study shows that the locations of the dump sites (Igwuruta, Eliozu, and Rumuolumini) were below the acceptable standard from roads, built-up, and water body. These will have severe consequences on the physical, social, and economic well-being of the people. Besides, the water quality which is key to the health of the people will be degraded to the extent that disease outbreak will be rampant. The water body in the study area is the most impacted land cover especially around Rumuolumini River. This justified that solid wastes management involves the integration of GIS software and remote sensing data in any geographic location. For further study of solid wastes in the study area, GIS and remote sensing data should be used to select suitable location for dump sites, which will meet the required standard of dump sites location relative to built-up areas. Secondly, additional environmental management agencies should be set up to argument the existing Rivers State Environmental Sanitation Authority (RSESA) which is already over stressed with increasing population of the city. Thirdly, the Rivers State Environmental Sanitation laws should be review to imposed stiffer penalty to defaulters of sanitation laws. These will regulate the habit of indiscriminate dumping of solid wastes in unauthorized locations in the city.

\section{Acknowledgement}

We specifically appreciate Mrs Benedicta U. for her assistance during site visit. She actually drove us to the dump sites. Finally, we commended the prayers and moral supports of our wives from the beginning to the end of this work. 


\section{References}

[1] Ranjith K. A. Sustainable Solid Waste Management in India, Nickolas J. T., and StanleyThompson (Eds.), Master Degree Thesis Summited to the Department of Earth and Environmental Engineering, Columbia University New York City, pp. 28, 2012.

[2] Asian Development Bank. Solid Waste Management in Nepal Current and Policy Recommendations, 6 ADB Avenue, Mandaluyong City, 1550 Metro Manila, Philippines, www. Adb.org, pp. 7, 2013.

[3] USAID. Environmental Guidelines for Small-Scale Activities in Africa, Solid Waste: Generation, Handling, Treatment and Disposal, pp. 3, 2009.

[4] United States Environmental Protection Agency. 2015 Hazardous Waste Report, pp. 1, 2015.

[5] Meena D., and Laura J. S. Application of GIS in MSW Management in India, International Journal of Engineering Research and Development, vol. 10, no. 10, pp. 24-32, 2014.

[6] Ogwueleka T. Ch. Municipal Solid Waste Characteristics and Management in Nigeria, Iran. J. Environ. Health. Sci. Eng., vol. 6, no. 3, pp. 173-180, 2009.

[7] Agwu M. O. Issues and Challenges of Solid Waste Management Practices in Port Harcourt City, Nigeria-A Behavioural Perspectives, Am. J. Soc. Mgmt. Sci., vol. 3, no. 2, pp. 83-92, 2012.

[8] Maity S. K., Bhattacharyay B. K., and Bhattacharyya B. Solid waste Management and Salt Lake Municipality- A GIS and MIS Approach, IJRRAS, vol. 13, no.2, pp. 461-468, 2012.

[9] Benedine A., Robert T. A., and Abbas I. I. The Impact of Spatial Distribution of Solid Waste Dumps on Infrastructure in Samaru, Zaria, Kaduna State, Nigeria Using Geographic Information Systems (GIS), Research Journal of Information Technology vol. 3, no. 3, pp. 113-117, 2011.

[10] ESRI. GIS for Public Works, 380 New York Street Redlands, California 92373-8100 USA, pp. 5, 2007.

[11] Surendra K. Y. GIS Based Approach for Site Selection in Waste Management, International Journal of Environmental Engineering and Management, vol. 4, no. 5, pp. 507$514,2013$.

[12] Ayo B., and Ibrahim B. Selection of Landfill Sites for Solid Waste Treatment in Damaturu Town-Using GIS Technigues, Journal of Environmental Protection, vol. 2, pp. 110, 2011.

[13] Duncan M. K., and Martin G. N. Application of GIS and Remote Sensing Technologies in Solid Waste Management: A Case Study of Nyahururu Municipality, International Journal of Science and Research, vol. 5, no. 4, pp. 342-349, 2015.

[14] Shweta K. Application of Remote Sensing and GIS in Solid Waste Management: A Case Study of Surroundings of River Yamuna, India, International Journal of Environmental Engineering and Management, vol. 4, no. 6, pp. 593-604, 2013.

[15] Ozeair A., and Mohsen S. Hazardous Waste Landfill Siting Using GIS Technique and Analytical Hierarchy Process, EnvironmentalAsia, vol. 3, no. 2, pp. 69-78, 2010.

[16] Ajith R. G., Edussuriya C. H., Chandrakanthi K. G., and Wimalathilake A. M. A. S. K. Application of GPS, GIS and Remote Sensing to Detect Potential Sites of Surface Contamination Through Solid Waste Dumping in Southern Province of Sri Lanka, ResearchGate, pp. 1-10, 2016.

[17] Moradeyo O. O. Investigation of Groundwater Quality Near a MUNICIPAL Landfill Site (IGQMLS), International Journal of Chemical Engineering and Applications, vol. 3, no. 6, pp. 366-369, 2012. 
[18] Chonattu J., Kavya P., and Puthenveedu S. P. H. Application of GIS and DRASTIC Modelling for Evaluation of Groundwater Vulnerability Near a Solid Waste Disposal Site, International Journal of Geosciences, vol. 7, pp. 558-571, 2016.

[19] Rajkumar N., Subramani T., and Elango L. Groundwater Contamination Due to Municipal Solid Waste Disposal- A GIS Based Study in Erode City, International Journal of Environmental Sciences, vol. 1, no. 1, pp. 39-55, 2010.

[20] David O. O. and Solomon I. Waste Management and Water Quality Issues in Coastal States of Nigeria: The Ogun State Experience, Journal of Sustainable Development in Africa, vol. 13, no. 6, pp. 207-217, 2011.

[21] Alphonce K., and Victoria M. T. GIS Application in Coordinating Solid Waste Collection: The Case of Sinza Neighbourhood in Kinondoni Municipalilty, Dar es Salaam City, Tanzania, Fig Working Week 2009, Surveyors Key Role in Accelerated Development, Eilat, Isreal, 3-8 May 2009, pp. 1-19, 2009.

[22] Nitin M., Ravindra J., and Bhalachandra D. International Journal of Computer Applications, vol. 100, no. 10, pp. 24-32, 2014.

[23] Niket S., Sonal V., and Jignesh P. Municipal Solid Waste Management of Anand City Using GIS Technique, International Journal of Engineering Research \& Technology (IJERT), vol. 3, no. 7, pp. 707-717, 2014.

[24] Richard J. U., and Ogba C. Suitability Analysis of Secondary School Accessibility in Andoni L.G.A, Rivers State, International Journal of Scientific \& Engineering Research, vol. 7, no. 1, pp. 969-976, 2016.

[25] John C. PancromaTM Satellite Image Processing Making Satellite BetterTM, Instruction Manual Version 101, www.PANCROMA.com, 2012.

[26] Pat S., Esad M., and Gyanesh C. SLC Gap-Filling Products Phase One Methodology, pp. $1-5,2004$.

[27] Landsat Technical Guide. Global Land Cover Facility, University of Maryland Institute for Advanced Computer Studies, Department of Geography, http://ltpwww.gsfc.nasa.gov/IAS/handbook/handbook_toc.html, pp. 1-2, 2004.

[28] Richard J. U. Object-Oriented Classification Using Aerial Photograph and Spot Image of Eagle Island Port Harcourt, Rivers State, Nigeria, International Journal of Advance Research, vol. 3, no. 12, pp. 11-23, 2015.

[29] Perumal K., and Bhaskaran R. Supervised Classification Performance of Multispectral Images, Journal of Computing, vol. 2, no. 2, pp. 124-129, 2010.

[30] Richards J. A., and Xiuping J. Remote Sensing Digital Image Analysis, $4^{\text {th }}$ Edition, Springer-Verlag Berlin Heidelberg, Germany, pp.194, 2006.

[31] Anderson J. R., Ernest E. H., John T. R., and Richard E. W. A Land Use and Land Cover Classification System for Use With Remote Sensor Data, Geological Survey Professional Paper 964, A Revision of the Land Use Classification System as Presented in U.S. Geological Survey Circular 671, pp1-41, 1976.

[32] Anji M. R. The TextBook of Remote Sensing and Geographic Information Systems, 3rd Edition, 4-4-309, Giriraj Lane, Sultan Bazar, Hyderabad-500 095-A.P, pp197, 2008.

[33] Heywood I., Cornelius S., and Carver S. An Introduction to Geographic Information System, 3rd Edition, Pearson Education Limited, Edinburgh Gate Harlow Essex CM20 2JE England, pp. 175, 178, 2006.

[34] Muhammad S., Abdul G., Ibtisam B., Muhammad S., and Nasir A. Application of GIS in the Spatial Analysis of Slums in Faisalabad, Pakistan, Sci. Int. (Lahore), vol. 25, no. 3, pp. 457-460, 2013.

[35] Khaled A. A. A. A. GIS-Based Mapping and Statistical Analysis of Air Pollution and Monitoring in Brisbane, Australia, Master Degree Thesis Queensland University of Technology, Faculty of Built Environment and Engineering, pp. 37, 2010. 
[36] Iyeneomie T., Valentine B. O., and Briggs-Karama M. A. The Impact of Municipal Solid Waste Landfill on the Environmental and Public Health in Port Harcourt and its Environs, Rivers State, Nigeria, Trend in Advanced Science and Engineering, vol. 3, no. 1, pp. 49-57, 2012.

[37] Sule J. O., Aliyu Y. A., and Umar M. S. Application of GIS IN Solid Waste Management in Chanchaga Local Government Area of Niger State, Nigeria, IOSR Journal of Environmental Science, Toxicology and Food Technology (IOSR-JESTFT), vol. 8, no. 9, pp. 17-21, 2014.

[38] Olusina J. O., and Shyllon D. O. Suitability Analysis in Determining Optimal Landfill Location Using Multi-Criteria Evaluation (MCE), GIS \& Remote Sensing, International Journal of Computation Engineering Research (IJCER), vol. 04, no. 6, pp. 7-20, 2014.

[39] UNEP. Municipal Solid Waste Open Dump site Juba, South Sudan, Preliminary Environment Assessment, pp. 8, 2013.

[40] Hunachew B., and Sandip B. Assessment of the Pollution Status of the Solid Waste Disposal Site of Addis Ababa City with Some Selected Trace Elements, Ethiopia, World Applied Sciences Journal, vol. 14, no. 7, pp. 1048-1057, 2011.

[41] U.S Environmental Protection Agency. California Solid Waste Management Study 1968 and Plan 1970, pp. 161, 171, 1971.

[42] Rhode Island Department of Environmental Management. What's the Scope on Wetlands, Frequently asked Questions about DEM's Freshwater Wetlands Program, pp. 1-53, 2008.

[43] Tiffany W., Jennifer T., Tom S., Karen C., Anne K., and Dave H. Direct and Impacts of Urbanization on Water Quality, Wetlands and Watersheds Article \#1, Center for Watersheds Protection, 8390 Main Street, $2^{\text {nd }}$ Floor Ellicott City, MD 21043, pp. 2, 2006.

[44] Florida State of the Environment1 Wetlands. A guide to Living with Florida's Wetlands, pp. 2-3, 1993. 